\title{
ERIKA KRŽIŠNIK
}

FILOZOFSKa faKULTETA UniverZe v LJUBLJANI

LJUBLJANA, SLOVENIJA

krzisnik.erika@ff.uni-lj.si

https://doi.org/10.17234/9789531755139.17

\section{ZOONIMI V SLOVENSKIH FRAZEOLOŠKIH PRIMERAH}

\begin{abstract}
Kulturološko, zlasti etnolingvistično, deloma tudi kontrastivnoanalitično zasnovana monografija o zoonimnih poimenovanjih v slovenščini sicer obstaja že nekaj časa (Keber, Živali v prispodobah 1, 2, 1996, 1998), vendar jezikovno gradivo v njej ni omejeno na frazeološke enote niti frazeološke enote $\mathrm{v}$ njej niso posebej obravnavane. $\mathrm{V}$ prispevku bo zato sistematično obdelan korpus primerjalnih frazemov z zoonimno komponento kot primerjalnim izrazom, in sicer glede na strukturno-semantične lastnosti (ustaljenost/variantnost in leksikaliziranost) in z vidika rabe $\mathrm{v}$ sodobni slovenščini.
\end{abstract}

Ključne besede: frazeologija, zoonimi, primerjalni frazemi, elektronski korpus tekstov

\section{Namen raziskave in metoda}

Predmet obravnave so primerjalni frazemi z zoonimno komponento (dalje PFZ), vendar ima raziskava dva splošnejša cilja. Prvi je sistematično pregledati strukturo in delno tudi pomen primerjalnih frazemov, pri čemer bomo ugotovitve Ž. Fink Arsovski (2002) o primerjalnih frazemih $\mathrm{v}$ hrvaščini (in primerjalno $\mathrm{v}$ ruščini) preverjali za slovenščino. Primerjalni frazemi v slovenščini so namreč ravno s strukturnega vidika razmeroma slabo raziskani. ${ }^{1}$ Ker je obseg prispevka omejen, se bo ob predstavitvah, npr. strukturnih skupin, omejili na reprezentativne vzorce, sicer pa opozorili na distinkcije, ki so morda posebej karakteristične prav za PFZ. Drugi cilj je s pomočjo elektronskih korpusov slovenskih tekstov preveriti rabo PFZ v slovenščini danes. Živalskim idiomatskim poimenovanjem (55 živali) v slovenščini je namreč posvečena že pred časom izšla monografija J. Kebra v dveh delih (Keber 1996, 1998). Avtor skuša evidentirati pomenske premike in raziskuje predvsem kulturološke vzroke zanje, manj ga zanimajo sistemska vprašanja o tem, s katere vrste jezikovnimi enotami - besedami ali frazemi (problem stalnosti) ${ }^{2}$ - so izražene in koliko oz. ali sploh še so prisotne $\mathrm{v}$ sodobni jezikovni rabi in $\mathrm{v}$ zavesti rojenih govorcev.

$1 \quad$ J. Toporišič (1985) je pisal o njihovi tematski podstavi, nekaj je kontrastivnih študij, najnovejše npr. Grošelj 2013, Vrbinc 2013, kar nekajkrat so primerjalni frazemi tudi tema diplomskih nalog, celo objavljenih (Temnik, Kalamar 2006). Del slovenskih primerjalnih frazemov je zbran v Hrvatsko-slavenskom rječniku poredbenih frazema (dalje HSRPF, Fink Arsovski et al. 2006), katerega slovenski del, ki je bil že preverjan s korpusom Fidaplus, je prispevala E. Kržišnik.

2 Prim. (Keber 1998: 45) nedoločnost v: »Druga naša strupenjača je gad, ki pomeni tudi »strupena kača sploh «, zato je v zvezi z njim nastalo precej izrazov in frazeologemov [...] (poud. E. K.), in nato primere kot »je imela strupen jezik, kakor verižasti gad zobe« (iz teksta I. Tavčarja, objavljenega 1888), 
1.1 To gradivo je bilo preverjeno najprej s slovarskimi viri (Pavlica 1962, $S S F,{ }^{3} S S K J,{ }^{4}$ $H S R P F)$, s čimer so bile izločene najbolj nestalne ali najbolj arhaične enote. Tako smo v izhodišču dobili korpus okrog $270 \mathrm{PFZ},{ }^{5}$ ki je bil v drugi fazi preverjan v elektronskih korpusih slovenskih tekstov. Za sodobno slovenščino obstajajo trije veliki korpusi in vsi so med seboj delno prekrivni: Fidaplus je referenčni korpus, ki obsega več kot 600 milijonov besed in vsebuje tekste od 1.1990 do 2006, kasneje je bil v celoti vključen tudi v 1,2-milijardni referenčni korpus Gigafida s teksti do 1. 2011, na podlagi katerega je nastal referenčni in iz Gigafide uravnoteženi korpus Kres, ki obsega 100 milijonov besed (iz zvrstno, zlasti funkcijskozvrstno, uravnoteženih tekstov). Največ smo uporabljali Gigafido - za raziskovanje frazeologije je pomembna zato, ker vsebuje količinsko največ gradiva in zajema najdaljše časovno obdobje (1990-2011), poleg tega pa je v njej zajet razmeroma obsežen del internetnih tekstov (16 \%), ki zaradi svojega govorno-pisnega karakterja deloma nadomeščajo odsotnost podatkov iz govorjenih tekstov. ${ }^{6}$

\section{Struktura in pomen PFZ}

Stalne primere (komparacije) se kot posebna skupina frazemov formalno najbolj neposredno identificirajo s prisotnostjo primerjalnega veznika. V slovenskih PFZ enako kot v veliki večini primerjalnih frazemov - so to kot, kakor in ko. V različnih slovarjih so evidentirani z različno distribucijo, na splošno velja, da je v SSKJ večkrat naveden kakor, v novejšem SSF pa kot. Gradivo v korpusih brez izjeme postavlja na prvo mesto veznik kot, ki je tako nemarkiran v vseh PFZ. Veznik kakor je šele druga in veliko redkejša izbira, izraz, v katerem se pojavi, kaže dolgotrajnejšo (tradicionalno) prisotnost $\mathrm{v}$ jeziku in večjo pisnost. Veznik $k o$ (redko celo $k$ ali $k^{\prime}$ ) je predvsem indikator govorjenosti (zgled v 3.1.1). ${ }^{7}$

kjer je problem vsaj status verižasti (ali gre za fakultativno komponento frazema ali za prosto aktualizacijo), ali »Žalil in obrekoval je po gadje vsakega poštenjaka [...] «, kjer je nedoločen status »izraza« po gadje (citirano mesto iz Trdine 1. 1886). »Izraz« Boj se hudega jezika huje kakor gad pikne pa ni niti določen glede na vrsto enote niti ni povezan s kakim konkretnim virom.

3 Keber je tudi avtor $S S F$, in če bi bilo jasno, kakšni so bili kriteriji za vključevanje frazemov vanj (prim. ugotovitve v zvezi z vključevanjem izbibličnih frazemov vanj v Kržišnik 2013), bi bilo lažje soditi o izbiri PFZ za ta slovar.

4 Tudi v SSKJ primerjalni frazemi niso dosledno uvrščeni v frazeološko gnezdo, temveč so celo večinoma umeščeni na začetek ilustrativnega gradiva. $O$ večji ali manjši ustaljenosti glede na to ni mogoče sklepati.

5 Približnost števila je posledica neodločenosti glede zgolj intenzifikatorske vrednosti in posledične izključne 2-delnosti zveze kot pes (prim. 2.2.2) in še nekaterih zvez, ki se pojavljajo kot 2- ali 3-delne (prim. 2.1).

${ }_{6}$ Korpus slovenskih govorjenih tekstov Gos sicer obstaja, a je za zdaj še premalo obsežen, da bi bil za frazeologijo lahko relevanten.

$7 \quad$ Že v SSKJ je raba ko v tej funkciji označena kot pog[ovorna]. 


\subsection{Strukturni vidik}

Osnovna struktura PFZ je tridelna: A+primerjalni veznik $+C$, pri čemer je A tretje $\mathrm{v}$ primeri (tertium comparationes), $\mathrm{C}$ pa primerjalna beseda (comparatum), npr. delati kot konj, zmešan kot kura. A-del ni vedno izražen in manjša skupina PFZ ima dvodelno strukturo, npr. kot pes, kot koza, kot fijakarski konj, kot ovce brez pastirja, kot berač uši, kot bi kravi iz riti potegnil. Razmerje med tri- in dvodelno strukturo je 87,6\%:12,3\%, kar pomeni, da tridelnost močno prevladuje, vsaj v slovarskih virih. Pregled rabe v Gigafidi kaže, da razmejitev ni tako preprosta in da je upoštevanja vredna tudi skupina, ki kaže prehajanje tridelnih PFZ v dvodelne in/ali soobstoj obeh struktur. Pri glagolskih tridelnih PFZ pri tem prihaja do spremembe kategorialnega pomena, npr. gledati/razumeti se kot pes in mačka 'zelo se prepirati, sovražiti se, ne marati se' - biti si kot pes in mačka 'sovražiti se' - biti kot pes in mačka 'biti sprta/sprti, sovražna/sovražni' - kot pes in mačka 'sovražna/sovražni'. ${ }^{8}$ Primeri (vsi ilustrativni primeri - razen izjemoma, kjer je na to posebej opozorjeno - so iz Gigafide):

že od ustanovitve obeh državnih domov, predstavniškega in svetniškega, se poslanci in svetniki gledajo kot pes in mačka // Prišlo je do spora in postala sta si kot pes in mačka // Kake interese pa so imeli z ohranitvijo vzhodnega bloka in Jugoslavije? NATO in JLA sta bila kot pes in mačka // Ste si strokovnjaki z zavoda in urbanisti še vedno v podobnem odnosu kot pes in mačka // Ali bosta tokrat neločljivi prijateljici ali pa kot pes in mačka // Te dni pa sta v New York kot pes in maček odpotovala drugače sicer gospoda Drnovšek in Kučan // Imela sva idealen zakon, tak, kot mora biti, včasih kot pes in mačka, potem kot stara zakonca, včasih kot mlada ljubimca.

Pri neglagolskih PFZ pri »krajšanju« ostaja nespremenjen tudi kategorialni pomen, npr. tiho kot miška in kot miška 'zelo (po)tiho', prost/svoboden kot ptiček na veji in kot ptiček na veji. Za prehajanje glagolskih PFZ prim. dalje 2.1.1.

2.1.1 Preden predstavimo ilustrativni primer notranje strukture PFZ, ${ }^{9}$ ne moremo mimo razmerij med njihovimi kategorialnimi pomeni, saj brez tega ilustracija nima ustrezne teže. Več kot polovica (53 \%) vseh PFZ je glagolskih (=Verb), pridevniških (=Adj) je 29 \% (krotek kot jagnje, spolzek kot jegulja, rumen kot kanarček, kot polit cucek, kot fijakarski konj), prislovnih (Adv) 15,3\% (tiho kot miška, kot pes, kot berač uši, kot fijakarski konj), strukturo enodelnega brezosebkovega stavka (=S) ima 2,4\% PFZ (zebe kot psa koga).

$8 \quad$ Seveda pa obstajajo tudi različni PFZ, ki z enakim C-delom nastopajo kot tridelni in dvodelni PFZ, npr. skakati kot koza 'na videz neenakomerno in skakaje hoditi, (nerodno) poskakovati sem in tja; na težkem terenu lahko in spretno hoditi', npr. »in potem sem kot koza skakala skozi metež po strmini gor « in kot koza 'trapasto, neumno', npr. »Stala sem tam kot koza, s fotografijami, ki sem jih lahko zadegala v smetnjak."

9 V Fink Arsovski 2002: 12-20. 
Zanimivo je, da med PFZ nismo našli nobenega samostalniškega (Sam=Subst). Morda bi to lahko bila zveza spomin kot zlata ribica 'slab spomin' v primeru:

»Po naključju sta se čez dober teden srečala. Ona vsa zardela, malo od mraza, malo od alkohola in malo zato, ker ima tako polt, ki odobrava zardevanje, s spominom kot zlata ribica se je smehljala in rekla [...].«.

Vendar je to edini primer take rabe ob 22 pojavitvah imeti spomin kot zlata ribica in 2 z elipso imeti (Še vedno ne morem verjeti, da v to, kar pišete, dejansko verjamete. Spomin kot zlata ribica, ni kaj-elipsa: imate). S samostalniškim kategorialnim pomenom namreč nastopa v obliki neprimerjalnega frazema spomin zlate ribice (v Gigafidi 33 zadetkov).

Pri dvodelnih PFZ imamo enako kot v PF nasploh (Fink Arsovski 2002: 27) primere razhajanja med strukturo in kategorialnim pomenom. Prim. za že navedenega kot $m i s ̌ k a$, ki je strukturno samostalniška zveza, njegov kategorialni pomen pa je ali pridevniški, npr. »Tam je bolj pohleven, je kot miška, le višina ga malo moti pri tem [...]«, ali prislovni PFZ: »Ko je dobil klobaso, se zame ni več zmenil. Kot miška sem se splazila po stopnicah navzdol in že sem bila zunaj.«

2.1.1.1 Notranja struktura PFZ - za predstavitev dajemo primer najpogostejše skupine, tj. glagolskih PFZ:

a) Glag $+k o t+\ldots$

- Sam $_{1}$ smrdeti kot dihur

- Sam $_{\text {predl }}$ ravnati (s kom) kot z živino

- $\quad$ Prid+Sam 1 (kaj) vleči se kot jara kača

- $\mathrm{Sam}+\mathrm{Sam}_{\text {predl }}$ vrteti se kot muha v močniku

- $\mathrm{Sam}_{1}+$ predlSamBZ ${ }^{10}$ gledati kot tele/bik v nova vrata

- $\mathrm{Sam}_{1}+\mathrm{Sam}_{4}$ skrivati (kaj) kot kača noge

- $\mathrm{Sam}_{1}$ in $\mathrm{Sam}_{1}$ gledati/razumeti se kot pes in mačka

- S (od)skočiti, kot bi koga kača pičila; lagati, kot pes teče

b) GlagBZ + kot $+\ldots$

- Sam imeti (dolg) vrat kot žirafa

- $\quad$ Prid+Sam 1 imeti spomin kot zlata ribica

- $\mathrm{Sam}_{1}+\mathrm{Sam}_{4}$ imeti jezik kot krava rep

2.1.1.2 Kvantitativni povzetek: dominantna struktura PFZ je

- $\mathrm{Glag}+k o t+\mathrm{Sam}_{1-6}(\mathrm{x}$-ati kot $\mathrm{y})-40 \%$

- $\operatorname{Prid}+k o t+\operatorname{Sam}_{1-6}(\mathrm{x}-$ en kot $\mathrm{y})-20 \%$

$10 \quad \mathrm{BZ}=$ besedna zveza (sintagma). 
Ti dve strukturi pokrivata torej več kot polovico vseh PFZ.

PFZ s strukturo SamBZ v C-delu slovarsko nemalokrat izkazujejo fakultativnost pridevniške komponente, prim. delati/garati kot (črna) živina, kar velja tako za glagolske kot tudi pridevniške PFZ, npr. siten kot (podrepna) muha. Podatki v korpusih presenetljivo kažejo, da se fakultativna komponenta precej pogosteje eksplicira kakor izpušča. Prim. delati/garati kot črna živina $117 / 27$ pojavitev : delati/garati kot živina 35/7, siten kot podrepna muha 14 : siten kot muha 9; zaščiten kot kočevski medved 161 : zaščiten kot medved 79.

\subsubsection{Paradigmatika PFZ}

Paradigmatika A-dela pri tridelnih PFZ pravzaprav ne kaže nobenih posebnosti (v primerjavi z obnašanjem v prostih sintagmah), kar je gotovo posledica dejstva, da komponenta $\mathrm{v}$ A-delu najpogosteje nastopa v svojem slovarskem pomenu (prim. kvantitativne podatke v 2.2.1). Zanimivejša je paradigmatika C-dela. Ker obravnavamo samo primerjalne frazeme $\mathrm{z}$ živalskimi poimenovanji, nas seveda zanima predvsem, kako se obnaša ta sestavina, torej lahko opazujemo slovarski kategoriji samostalnika, to sta števnost in spol, ter gramatično kategorijo sklona.

2.1.2.1 Glede kategorije sklona se zoonim obnaša v skladu s sintaktično funkcijo, ki jo ima v primerjalnem odvisniku kot $S$ : subjekt=Sam ${ }_{1}$ bežati, kot bi (koga) sršeni podili, večinoma je seveda eliptičen: jesti kot pujs < (jesti,) kot je pujs, delati s čim kot svinja $z$ mehom $<$ kot dela svinja z mehom, objekt=Sam ${ }_{4}$ pobiti koga kot zajce $<$ kot se pobije zajce, $\mathrm{Sam}_{3}$ godi se komu kot črvu v loju < kot se godi črvu v loju, Sam ${ }_{2}$ je koga kot rusov $<$ kot je rusov. ${ }^{11}$ Redko izjemo predstavlja C-del, v katerem zoonim zaradi popolne desemantizacije dobi(va) zgolj pomen intenzifikatorja (več o tem prim. v 2.2.2). Eden takih je kot pes, pri tem PFZ je poleg sintaktični funkciji ustrezne oblike, npr. premlatiti koga kot psa < kot se premlati psa, že mogoče najti tudi rabe, kot je v naslednjem primeru: »Že naslednji dan me je začelo boleti 'kot pes'. Zato sem dobival tablete za lajšanje bolečin.« - kar seveda ni < *boli koga kot boli pes.

Neposredna sintaktična povezanost zoonima z glagolom v A-delu (npr. da bi enačili bati se psa = bati se kot psa) je samo navidezna, kar se pokaže pri neglagolskih PFZ, prim. pridevniškega: »Za začetek smo pripravili zgodbo bratov [...], iznajdljivih in pridnih kot mravlja«. Pridevniški A-del pridnih se ujema z zunajfrazemskim sintaktičnim jedrom bratov, samostalniški zoonim mravlja pa z obliko (sklonom) elidiranega pridevnika pridne (< pridnih, kot so pridne mravlje). To je vzrok za to, da $» / \mathrm{p} /$ romjena oblika pridjeva u A-dijelu ne povlači automatski za sobom i primjenu oblika imenice $u$ C-dijelu«, kakor ugotavlja Ž. Fink Arsovski (2002: 22) v zvezi s primerom »S užasom sam promatrala muškarca, pijanog kao svinja«.

11 V zadnjem primeru gre za t. i. logični subjekt. 
2.1.2.2 Kategorialni pomen števnosti, ki se kaže $\mathrm{z}$ gramatično kategorijo števila, zoonimna komponenta v PFZ praviloma ohranja, če to le dovoljuje pomen frazema. ${ }^{12}$ Res je mogoče opaziti težnjo po ohranjanju izodiščne, praviloma edninske oblike samostalnika (zoonima), vendar to ni izključno pravilo niti pri popolnoma desemantizirani komponenti ${ }^{13}$ kot je fuks v frazemu len kot fuks, prim. »jih je še vedno na sto tisoče in več tistih, ki ostajajo leni kot fuksi«. Načeloma je obnašanje zoonima glede izražanja kategorije števila mogoče označiti kot regularno, torej brez posebnosti, ki bi potrjevale frazeme kot anomalne enote, pri čemer v regularnost sodi tudi dejstvo, da je nemarkirana ednina, kar pomeni, da ednina lahko (vendar ne nujno) nadomešča tako množino kot dvojino: ${ }^{14}$

Vendar je zvit kot lisica. // spet drugi so želeli biti zviti kot lisica //»Zvita sva kot lisici!« je pribil Koyo. // Ženske so res zvite kot lisice. // Tatovi so bili zviti kot lisice.

Podobno ugotavlja tudi Ž. Fink Arsovski (2002: 23) za vse PF, ${ }^{15}$ vendar kot izjemo navaja primer: »Ima pak slučajeva kada imenica ostaje u jednini iako je glagol ili pridjev u množini: Kad idemo u školu, dani se vuku kao puž.« Verjetneje je, da gre v tem primeru za nemarkiranost ednine, ki pač povsem regularno (tudi zunaj frazeoloških enot) lahko nadomešča množino. Za slovenski ustreznik navedenega hrvaškega frazema ohranjanja ednine ne moremo potrditi kot pravilo, najsi gre za glagolski (v osnovni varianti vleči se ali kako drugo varianto z glagolom premikanja + kot polž) ali pridevniški PFZ počasen kot polž, prim. rabo v množini: »Lačne, utrujene in neosredotočene uslužbenke in uslužbenci se vlečejo kot polži« in »Vlada in Logarjeva trdita, da so davkarji počasni kot polži«, vendar tudi v ednini: »Sivi zimski dnevi se lahko vlečejo kot poľ̋«. V Gigafidi ni nobenega primera, ko bi zoonim polž ostal v ednini, če samostalnik v subjektu, rabljen v kontekstu, zahteva pridevnik A-dela počasen v množini.

12 Od PFZ tega ne dovoljuje množiti se kot zajci, ker pomen PFZ zahteva subjekt v množini, ali tip je koga kot kobilic 'veliko'.

13 Ljudska etimologija povezuje fuksa s starim konjem, ki je utrujen in zato počasen. V etimološkem slovarju M. Snoja (Snoj 1997: 133) je sami besedi fuks sicer res pripisan pomen 'konj rjavkasto ali rumenkasto rdeče barve', z razlago "prevzeto iz nem. Fuchs v enakem pomenu, kar je prvotno metaforično uporabljeno nem. Fuchs 'lisica'«. Vendar za frazem len kot fuks Snoj predvideva drugačno etimologijo, ki »temelji na drugi metaforični rabi, verjetno na pog. nem. potrjenem pomenu 'star, izkušen vojak'« z razlago, da so »/s/tari vojaki [...] zviti (kot lisice) in poleg tega slovijo po lenobi«. Navaja pa še drugo možnost, in sicer, da bi fuks v len kot fuks temeljilo na lat. fükus 'trot' (prim. v slovenščini le še redko rabljeni sinonimni PFZ len kot trot), a kot pravi Snoj, »v tem primeru vmesni členi pri izposoji niso znani«.

14 Zlasti dvojina je v frazeologiji nasploh redka in vezana predvsem na pojavljanje ob števniku, v PFZ npr. kot dva golobčka.

15 Pri tem se omejuje na kategorijo »broja imenice u nominativu« in res je, da je vsaj pri PFZ teh največ, vendar pa lahko podobno ugotovim tudi za samostalnik v akuzativu, npr. zoonim maček $\mathrm{v}$ zebe (koga) kot mačka se pri ustreznih sintagmatskih pogojih lahko rabi tudi v množini: »[...] povrh vsega pa nas je še zeblo kot mačke [...]. « Kot rečeno, to ni obvezno, v primeru Sredi poletja naju zebe kot mačka pa je oblika mačka homonimna ( mačka = akuzativ ednine = akuzativ dvojine). 
PFZ (kdo) tajiti/skrivati (kaj) kot kača noge, ki ob 94 pojavitvah v Gigafidi, od katerih jih ima 48 kontekstualni subjekt v množini, nima izkazane niti ene rabe z zoonimom v množini, je napeljeval na misel, da bi morda kategorija števila bila reducirana ali vsaj irelevantna pri zoonimih tistih C-delov, ki ob elipsi predikata ohranjajo več stavčnih členov (npr. poleg subjekta še objekt ali prislovno določilo), vendar je natančnejši pregled tega tipa PFZ pokazal, da tudi v tej skupini zoonimna komponenta ohranja kategorijo števila in jo lahko izkazuje z ujemanjem. To se seveda najbolje kaže pri razmeroma pogosto rabljenih PFZ tega tipa. Tako se delati/ravnati s kom/čim kot svinja z mehom ob množinskem subjektu rabi zoonim svinje (mn.) 30-krat (od skupaj 368 pojavitev), kot ptiček na veji 19-krat ptički (od skupaj 107 pojavitev), 5-krat (od 65 pojavitev PFZ gledati kot tele v nova vrata) celo gledati kot teleta v nova vrata ${ }^{16}$ enkrat (od 30 pojavitev) množina mačke v »te svoje članke sem nosil kot mačke mlade« in prav tako osamljena raba v internetnem tekstu »rdeči lažejo kot psi tečejo« (od 150 pojavitev lagati, kot pes teče).

Prilagajanje v številu je mogoče najti celo pri PFZ ( $k d o / k a j)$ iti/lepiti se na (koga/ kaj) kot muhe na med, katerega slovarska oblika se tako v SSKJ kot v SSF navaja z zoonimom v množini, kar z 59 primeri rabe potrjuje tudi raba v korpusu (vendar so vsi razen enega v stavku s subjektom v množini, torej lepijo se kot muhe). Mogoče je najti 5 pojavitev z zoonimom v ednini, od katerih je vsaj ena povsem sprejemljiva: »Nanjo so se moški lepili kot muha na med [...] « Seveda to lahko proglasimo za napačno rabo, a vendar dodatno potrjuje prisotnost kategorialnega pomena števnosti $\mathrm{v}$ zoonimu.

2.1.2.3 Popolnoma drugače se zoonimna komponenta v C-delu obnaša glede kategorije spola. To je razumljivo, saj je spol samostalniku imanentna kategorija, ki se pri poimenovanjih živali tudi zunaj frazeologije redkeje ujema z naravnim spolom. Pri njih je gramatični spol poimenovanja glede na naravni spol (samec, samica) praviloma mnogo bolj nediferenciran (npr. samo ž. kamela, samo m. črv, toda m. lev in ž. levinja itd.) kot pri poimenovanjih za človeka (npr. pripadniki naroda, nosilci poklicev in drugih funkcij). A tudi za ta poimenovanja v C-delu PF Ž. Fink Arsovski ugotavlja: »Zanimljiv je slučaj trodijelnih poredbenih frazema s etnikom u C-dijelu (pušiti kao Turčin, piti kao Rus) gdje su moguće promjene broja imenice, ali nije ovjerena upotreba adekvatnih etnika ženskoga roda.«

Nekateri PFZ imajo preprosto samo en zoonim, čeprav zunaj frazema obstajata poimenovanji za oba člena živalskega para, npr. lačen kot volk, čeprav volk - volkulja, lahko člena para ločeno nastopata v različnih frazemih, npr. kura in petelin: zmeden/

$\overline{16}$ Kar je zaradi posebne sklanjatve posebej nenavadno. Da ob samo devetih pojavitvah PFZ z variantnim zoonimom gledati kot bik v nova vrata in samo enem subjektu s samostalnikom v množini ni rabe bik v množini, ni nenavadno. 
zmešan kot kura, toda kot petelin na gnoju, tretji imajo en sam zoonim, ki predstavlja hipernim, npr. skrivati (kaj) kot kača noge. Te vrste PFZ v subjektu nimajo po (gramatičnem in/ali naravnem) spolu določenega odnosnega agensa ali nosilca lastnosti $v$ subjektu. Prim.

skače levo in desno, skratka je (za zunanjega opazovalca) zbegan kot kura // »Danes si bila zmešana kot kura.« // Važna sem kot petelin na gnoju // se ni dal motiti moški in se pred njo postavil kot petelin na gnoju.

Nekateri PFZ imajo v zoonimni komponenti glede na spol variantno poimenovanje, npr. ponavljati kot papiga/papagaj, zvit kot lisica/lisjak, pri čemer je prvo od para hkrati tudi hipernim za vrsto živali, zato je pričakovano, da je glede na spol nediferencirano, medtem ko naj bi bilo drugo poimenovanje $\mathrm{v}$ tem smislu specificirano. ${ }^{17} \mathrm{Kljub}$ temu za frazem ponavljati kot papagaj, ki ima v Gigafidi dovolj visoko frekvenco rabe (ki je zvit kot lisjak nima - le 4 pojavitve), najdemo redke primere, ki se brez posledic za pomen tega ne držijo: »Igrala sem otroške gledališke vloge in kot papagaj ponavljala kretnje in besedila."

Kot po spolu zares specificirano rabo PFZ je pravzaprav mogoče opredeliti samo primere, ko po spolu diferenciran zoonimni člen para prinaša v PFZ tudi kak specifičen pomen. Tako je v primeru boriti se kot lev in boriti se kot levinja, ki imata skupni del pomena 'zelo pogumno in vztrajno se boriti', samo boriti se kot levinja pa ima še dodatno pomen 'žrtvovati se za svoje otroke/družino' in je torej večpomenski. V okviru skupnega pomena je boriti se kot lev po spolu nediferenciran, samo ženske pa se borijo kot levinje $\mathrm{v}$ obeh pomenih:

(a) skupni pomen:

Boril se bom kot lev in sem optimist.

Judith Howard se je borila kot lev, da bi ga obdržala.

Soigralci so se borili kot levi, zato smo zasluženo zmagali.

Moje igralke so se borile kot levinje. Zelo sem ponosen na svojo ekipo [...].

(b) specializirani pomen

"Rekla je, da se je mami borila zame kot levinja," sem rekla [...].

Za družino se bori kot levinja [...].

In končno, edini po spolu specificiran je v slovenščini, kot kaže, PFZ kot koza 'trapasto, neumno', ki je obvezno v relaciji z nosilko lastnosti ženskega spola v kontekstu. Primer gl. v op. 8.

17 Posledica tega je tudi dejstvo, da je raba variante s spolsko nediferenciranim zoonimom frekventnejša od spolsko specificirane variante, prim. ponavljati kot papiga (108-krat)/kot papagaj (75), zvit kot lisica (29)/kot lisjak (4). 


\subsection{Pomenski vidik}

V nadaljevanju se bomo omejili na prikaz stanja pri PFZ glede na pomen A-dela in na premislek o statusu C-dela kot t. i. intenzifikatorja. A pred tem bomo padli v zanko, kar se frazeologom dostikrat zgodi, namreč to, da pri razpravljanju o pomenu frazemov zaidejo v diahronijo. Naš namen to nikakor ni, kljub temu pa ne moremo mimo podatkov, ki se tičeta tudi nastanka dveh slovenskih PFZ.

Prvi je suh kot trska 'zelo suh', ki sem ga v nabor PFZ vključila zaradi podatka o njegovem motivacijskem izhodišču v razdelku o izvoru v SSF (Keber 2011: 997): "Sestavina trska v osnovnem pomenu in kot poimenovanje ribe je prikladna za primerjanje suhosti, mršavosti koga.« Avtorjeva formulacija je na videz preprosta, a v bistvu neodločena. V slovenščini namreč obstajata homonima trska 'odsekan, odlomljen tanek, podolgovat kos lesa' (»V osnovnem pomenu «, ${ }^{18} \mathrm{kajti} 2$. pomen je že preneseni 'zelo suh človek') in trska 'velika morska riba [...]'. Po razlagi v SSF naj bi bila motivacija torej kar dvojna - zlasti drugo, tj. »kot poimenovanje ribe«, podpira tudi ekvivalentni hrv. PFZ suh/mršav kao bakalar 'zelo suh' (bakalar je po Aniću 2000: 'riba sjevernih mora (...), priređuje se sušena [...]' in ga SSF prav tako navaja. Podatek, dobljen na konferenci o animalististični frazeologiji, katere prispevke prinaša ta zbornik, in se nanaša na slovaški ekvivalent tega PFZ (tudi tega navaja SSF) chudý ako trieska, pravi, da je $\mathrm{v}$ tem primeru motivacija zanesljivo '[...] tanek, podolgovat kos lesa', kajti v slovaščini trieska $\mathrm{v}$ tem pomenu ni homonimna s poimenovanjem ribe, ki je treska (prim. Školský slovník 2009: trieska 'tenký odštiepený kúsok dreva' in treska 'druh morskej ryby[...]). Temu lahko dodamo vsaj še naslednje podatke: (a) znotrajjezikovni: sinonimna PF v slovenščini sta suh kot prekla in suh kot zobotrebec, ki imata oba podobno motivacijo (kos lesa) - prekla 1. 'tanjši kol [...]' (2. 'zelo velik in suh človek'), zobotrebec 'na obeh straneh priostrena, navadno lesena paličica [...]'; (b) zunajjezikovni: po podatkih naših primorskih študentov, ki so jih dobili od ribičev, je ta riba poimenovana trska samo, dokler je nesušena, sušeno trsko imenujejo polenovka - navsezadnje nas o tem kar na dveh mestih prepričuje tudi SSKJ: v geslu trska $\mathrm{z}$ ilustrativnim primerom polenovka je posušena trska, in $\mathrm{v}$ geslu polenovka $\mathrm{s}$ pomensko razlago 'posušena riba trska'. ${ }^{19}$ Po vsem tem je verjetno motivacija slovenskega PFZ precej bolj jasna in verjetna - celo ljudska etimologija trske iz frazema ne bi motivacijsko povezovala $\mathrm{z}$ ribo. ${ }^{20}$

Drugi PFZ, ki zasluži premislek o razmerju med motivacijo in sodobno rabo, je je koga/česa kot rusov. Keber v SSF razlaga, da motivacija etimološko sicer »temelji

18 SSKJ frazem navaja $\mathrm{v}$ tem geslu in pod tem pomenom.

19 A tudi polenovka je tvorjena iz poleno 'razžagan neobdelan kos lesa za kurjavo'!

20 Iz nabora PFZ je izločen tudi frazem pijan kot mavra - čeprav etimologija komponento mavra delno povezuje tudi s pomenom (dial.) 'črna ali marogasta krava'. Izločili smo jo zaradi podatka o varianti pijan kot božja mavra, ki to komponento povezuje z mavrico (dial. mavra) 'barvni lok na obzorju, nastal zaradi loma sončnih žarkov v vodnih kapljicah' (prim. Keber 2011: 401). 
na številnosti žuželk, med njimi tudi ščurkov, rusov, kobilic, ki se v ugodnih pogojih izredno hitro množijo in postanejo velika nadloga«, vendar pa hkrati ugotavlja, da se po ljudski etimologiji rus, ki v slovenščini ni ravno splošno znano dialektalno poimenovanje za ščurku podobno žuželko (ni pa res, da ni nikakršne asociacije: tudi SSKJ navaja sicer dialektalni izraz ruska za rdečo mravljo, ki je zaradi bolečega pika še kako nadležna), »navezuje na Ruse« in njihovo številčnost. ${ }^{21}$ Nas bo seveda zanimalo, koliko se ljudska etimologija odraža $v$ rabi. Ker so po slovenski pravopisni kodifikaciji imena pripadnikov narodov tretirana kot lastna imena in se zato od nekdaj pišejo $\mathrm{z}$ veliko začetnico, to ni težko preveriti. V Gigafidi z iskanjem »kot rusov« dobimo 52 zadetkov: veliko začetnico (Rus) ima 47 primerov, od tega je slaba četrtina lastnoimenska raba, vse drugo je frazeološko; z malo začetnico (rus) je samo 5 primerov - od tega se trikrat nanaša na razlago frazema, dvakrat je aktualizacija (prenovitev) frazema, npr. »Ja, Rusov je že kot rusov in potencial imajo, ampak naučiti še morajo še dosti.« Razmerje velika : mala začetnica v je koga kot R/rusov je 36 : 5 (za veliko začetnico). Da začenja prevladovati »nova« motivacija, kaže poleg številčnega razmerja tudi to, da je nosilec lastnosti $(k o g a)$ v veliki večini 'človeško+' (pravzaprav samo dvakrat ne). Močno prisotnost prepričanja pri rojenih govorcih, da gre za količino ljudi, ne česa drugega, kaže primer: »[...] da v Sloveniji takrat, ko hočemo opisati ogromno število ljudi, rečemo, da jih je kot Rusov. «Če je torej v SSF slovarska oblika še je koga/česa kot rusov, lahko $\mathrm{v}$ prihodnosti pričakujemo omejitev na $\operatorname{kog} a\left(\right.$ 'člov+'). ${ }^{22}$

2.2.1 Po tem delnem ekskurzu, ki pa se kljub temu še kako tiče sodobnega stanja, se v okviru pomenskih lastnosti PFZ vrnimo v sinhronijo. Zato bomo v zvezi z (ne)motiviranostjo v PFZ namesto o skupih (rusko fr. sočetanie), sklopih (edinstvo) in zraslekih (sraččenie) raje govorili o komponentnih in globalnih frazemih (Mršević-Radović 1987: 63-68), kar pomeni, da globalnih frazemov ne bomo dalje delili na sklope in zrasleke, medtem ko so komponentni frazemi prekrivni s frazeološkimi skupi. Tako bomo le poenostavili razporejanje frazeološkega materiala glede na pomen A-dela, kar je za PF relevantno. Sinhroni vidik bo PFZ tipa zvit kot lisica uvrstil med komponentne, čeprav prvi pomen zvit ni 'prebrisan', temveč 'neraven' - s tega vidika je globalen sinonimni frazem zvit kot kozji rog 'prebrisan' (ki v naš nabor ni vključen), PFZ zvit kot lisica pa ima pomen 'zelo prebrisan'. Nasprotno pa PFZ imeti jezik kot krava rep uvrščamo med globalne frazeme, in to ne glede na to, ali je kot krava rep razširitev ali elidirani del in je imeti jezik (< imeti dolg jezik) samo posledica elipse.

Glede na povedano lahko ugotovimo, da je velika večina PFZ komponentnih, več kot $80 \%$. Večinoma je torej A-del nedesemantiziran, kar samo potrjuje podatke, navedene v Fink Arsovski (2002: 29). Primeri:

$\overline{21} \quad$ Globinsko so seveda Rusi motivacijsko prisotni v samem poimenovanju rus (SSKJ s kvalifikatorjem še navaja arhaični pridevnik rus 'rdeč').

22 Če zapis velike začetnice Rusov ne bo dokončno prevladal, tega ne gre pripisati »pravilni« motivaciji, temveč dejstvu, da v slovenski pravopisni kodifikaciji močno prevladuje tendenca, da bi izlastnoimenska poimenovanja, nastala s pomenskim prenosom, pisali z malo začetnico (prim. variantni zapis ahilova/Ahilova peta). 
debel kot pujs/prašič/svinja, močan kot bik/konj, moker kot miš/cucek, rdeč kot (kuhan) rak/puran, priden kot mravlja/mravljica/čebela/čebelica, siten kot (podrepna) muha; premlatiti (koga) kot psa/mačka, pisati kot kura, skrivati/tajiti (kaj) kot kača noge, spati kot polh, spoznati se (na kaj) kot zajec/krava na boben, zdrav kot riba (v vodi).

Globalnih frazemov je kakih $10 \%$, npr.

slep kot kura 1. 'slabo, nejasno videč; 2. 'zaslepljen', igrati se (s kom) kot mačka z mišjo 'imeti (koga) v popolni oblasti';

hoditi/smukati se okrog (koga, česa) kot mačka okrog vrele kaše 'ne upati se lotiti jedra problema';

imeti sedem življenj kot mačka 'biti trdoživ, biti sposoben prenesti velike nesreče itd. brez usodnih posledic'; preščipnjen kot osa 'ozek v pasu';

tiščati glavo v pesek kot noj 'ne hoteti videti, sprejeti neprijetne resnice';

vrteti se kot muha v močniku 1. 'nesmotrno se gibati, begati sem in tja, 2. 'brezuspešno si prizadevati priti iz neprijetnega položaja'.

Preostanek predstavlja skupina PFZ, ki gredo tako v eno kot drugo skupino, in sicer (a) glede na različne pomene; (b) glede na variantne sestavine v A-delu, npr.

(a) spreminjati barve kot kameleon - komponentni: 'hitro spreminjati prepričanje zaradi koristi', globalni: 'biti nenačelen iz koristoljubja;

(b) globalni: gledati se kot pes in mačka 'sovražiti se' > komponentni: sovražiti se kot pes in mačka 'zelo se sovražiti'; 23

Poseben, zato tudi posebej zanimiv je primer zveze cepati/padati/umirati kot muhe, ki predstavlja dva homonimna frazema: (a) cepati kot muhe $\mathrm{z}$ variantama padati kot muhe in umirati kot muhe - vsi s pomenom 'umirati v velikem številu', tudi 'propadati' (najpogosteje, a ne izključno ob patiensu s pomenom 'neživo'), pri čemer sta prvi dve varianti globalna frazema, tretja je komponentni, in (b) komponentni frazem, prav tako variantni, padati (redko tudi cepati) kot muhe 'padati v velikem številu'. Primeri:

(a) Čebele cepajo kot muhe. // Pravi napad besa je doživel, ko so ga obvestili, da eden njegovih generalov v Albaniji po večerji sklada librete za lastno dušo, medtem ko njegovi vojaki padajo kot muhe in se njegova vojska umika. // Slovenci na cestah umiramo kot muhe. // Ampak ko kot muhe cepajo podjetja, na biroju za brezposelne je vse več rosno mladih [...].

$\overline{23}$ Ali je intenziteta tukaj res tako relevantna, bi bilo treba $\mathrm{v}$ korpusnem materialu še natančneje pregledati. 
(b) Imeli smo izvrstne švicarske protiletalske topove oerlikon. Takšnih ni na svetu. Iraški migi so cepali kot muhe. // Kranjskogorski dohtarji so v obupu vili roke, po beli lepotici pa so sprehajalci padali kot muhe in si lomili ude! // Nesporni vladar ultratekov je odbil napade cele kohorte Japoncev, ki se vsako leto privalijo do Aten in potem med tekom cepajo po tleh kot muhe [...].

2.2.2 Zaradi prevladujoče nedesemantiziranosti A-dela se v PFZ desemantizirani C-del zelo pogosto uveljavlja z intenzifikatorskim pomenom 'zelo', 'veliko', 'močno', 'v veliki meri', 'v velikem številu': smrdeti kot dihur, piti kot žolna, reven kot cerkvena miš, zaščiten kot (kočevski) medved; lagati, kot pes teče. Pravzaprav je mogoče reči, da ima C-del tudi v primeru, ko v pomenu PFZ participira še z drugimi pomenskimi sestavinami, praviloma vedno tudi pomen intenzifikatorja, prim. spati kot zajec in teči kot zajec - v prvem primeru ni samo 'rahlo spati', temveč 'zelo rahlo spati' in v drugem 'zelo hitro teči'. Po drugi strani pa C-del tudi v primeru, ko ima primarno intenzifikatorski pomen, uveljavlja večinoma poleg tega še kako dodatne pomenske sestavine - v zelo skrajnih primerih je to mogoče dokazovati s primeri sopomenskih frazemov, npr. molčati kot riba 'zelo (= dolgo, vztrajno) molčati = sploh ne govoriti' v primerjavi z molčati kot grob 'zelo molčati = ne govoriti o določeni stvari' (oznaka predmeta/vsebine tistega, kar se ne sme povedati) ali z molčati kot rit 'ne /upati si/ govoriti' (oznaka karakterja tistega, ki ne govori).

Kot prave intenzifikatorje lahko označimo dvodelne PFZ kot pes ter zaradi emocionalne konotacije (vulgarno) neknjižna kot svinja in kot prasica. Razloga za to sta dva: (1) rabijo se ob sintaktično jedrnih besedah z različnim kategorialnim (glagoli, pridevniki, prislovi in samostalniki) in denotativnim pomenom, celo pri najpogostejših, to so glagoli in pridevniki, ni mogoča niti omejitev na določena pomenska polja; (2) kot že omenjeno v 2.1.2.1, je mogoče najti rabe, ki kažejo, da se intenzifikatorji obnašajo sintaktično neustrezno, prim. (poleg že tam navedenega) še: »Čeprav je pes, ga pogrešam kot svinja.« Primerov ni zelo veliko, tako da bi težko trdili, da se pravi intenzifikator tako obnaša praviloma, vendar je treba upoštevati, da smo preverjali korpuse, ki so predvsem pisni. Relevantnejši bi bil korpus govorjenih tekstov, zlasti seveda neformalnih. Verjetno je predvsem to vzrok, da pri še knjižnem kot pes tudi ne najdemo rabe, ki ne bi kazala njegove negativne konotacije. ${ }^{24}$ Med kolokatorji (507 glagoli in 367 pridevniki) namreč ni najti primera s pozitivnim konotativnim delom pomena. ${ }^{25}$ Pri štirikrat manj pogosti rabi kot svinja, ki je kot intenzifikator omejen na neknjižno, zlasti govorjeno rabo, ga je že mogoče najti: ${ }^{26}$

24 Prim. pravi intenzifikator kot hudič, ki niti tega dela pomena ne uveljavlja več: »Ni kaj, Patrick Swayze po 17 letih še vedno pleše kot hudič, ali še boljše [...].«.

25 Dve rabi, »Kuža, zaljubljen kot pes« in »Dober kot pes«, sta nerelevantni, ker gre v prvem primeru za aktualizacijo (prenovitev), v drugem pa nimamo konteksta, da bi lahko presojali.

26 Z iskanjem kot pes dobimo 1960 zadetkov, kot svinja 588, kot prasica 30. Da v samo 30 konkordancah ni rabe s kolokatorjem s pozitivnim konotativnim pomenom, že zaradi tega ni nenavadno. 
$\mathrm{Na}$ dlani je bilo, da bo folksi krepnil na skalah, kake tri metre nižje, če takoj in nemudoma ne ukrepava. Erik je skušal speljati, ups, pa sva bila samo še deset centimetrov od roba. Zbila sva kamne in veje pod gume, stlakovala pot v blago vzpetino, jaz sem porival, Erik pa je lepo z občutkom dodal gas. Blaten in zadovoljen kot svinja sem se ozrl na masaker, ki sva ga priredila krhki naravi.

2.2.3 Prevladujoča konceptualna polja pri PFZ so naslednja: ${ }^{27}$

- način premikanja (gibanje): odskočiti, kot bi (koga) gad/kača pičil/a, glagol premikanja+ kot polž, skakati kot koza, letati okrog kot kura brez glave, zagnati se (kam) kot svinja v buče, teči kot zajec;

- lastnosti človeka: pamet/neumnost kot fijakarski konj, kot tele/teliček, gledati kot tele/bik v nova vrata, zmešan kot kura, spoznati se (na kaj) kot zajec/krava na boben, zvit kot lisica; pogum/strahopetnost pogumen/hraber kot lev, boriti se kot levinja; ponižnost/domišljavost kot petelin na gnoju, napihnjen kot puran, napihovati se kot žaba, šopiriti se kot pav; trma (vztrajnost) trmast kot bik/mula/osel;

- odnosi: do dela garati/delati kot konj/kot (črna) živina, priden/marljv/delaven kot mravlja/mravljica/čebela/čebelica; do jedi jesti kot ptiček/piščanček/vrabček, jesti kot pujs, lačen kot volk; do (so)človeka delati (s kom) kot svinja z mehom, delati/ ravnati (s kom) kot z živino; količina je (koga) kot rusov/kot čebel v panju/kot kobilic;

- stanje: jeza gledati kot ris; pijanost pijan kot krava/svinja, piti kot živina; spanje spati kot polh/jazbec/zajec; svobodnost kot ptice pod nebom, svoboden/prost kot ptiček na veji, živeti kot ptiček na veji;

- zunanjost človeka: debelost/suhost debel kot prašič/svinja, suh kot pajek.

\section{Raba PFZ - korpusni podatki}

V nadaljevanju nas zanima, kaj nam o zbranem gradivu in PFZ sploh lahko razkrijejo podatki v elektronskih korpusih (podatke prim. v 1.1), kako lahko pomagajo pri interpretaciji njihove prisotnosti v slovenščini. Poleg že doslej navajanih primerov in podatkov iz Gigafide je za splošno orientacijo v okviru živalskih poimenovanj in njihove sposobnosti graditi pomenske prenose (komparacije, metafore, metonimije ...) v slovenskem jeziku najprej zanimiv podatek iz (uravnoteženega!) korpusa Kres, ki smo ga dobili z opazovanjem kolokabilnosti kot s prvim Sam na desni. Na tem mestu se pojavi 18.999 različnih Sam, med pregledanimi 4000 se glede na faktor kolokabilnosti (LL, ki prinaša oceno predvidljivosti in medsebojne napovedljivosti pojavljanja) od zoonimov pojavijo (a) na prvih dvajsetih in (b) na zadnjih dvajsetih mestih naslednji (številka pomeni mesto v zaporedju med Sam):

(a) pes (32.), riba (69.), kača (74.), volk (96.), zajec (114.), ptica (135.), muha (183.), svinja (188.), žival (197.), spužva (204.), podgana (233.), ptiček (235.), ris

27 Upoštevamo razvrščanje po Fink Arsovski 2002: 37-61. 
(238.), mravljica (240.), opica (253.), sraka (273.), pav (280.), kura (293.), miš (295.), slon (312.)

(b) račka (3995.), jazbec (3940.), piton (3825.), rus (3787.), kljuse (3763.), ježek (3750.), žabica (3730.), štorklja (3702.), žirafa (3666.), gosenica (3651.), vran (3646.), mustang (3618.), putka (3551.), odojek (3547.), veper (3528.), jastog (3502.), rakovica (3457.), žužek (3419.), gad (3402.), aligator (3400.)

Med podatki za zadnjih 20 zoonimov ni relevanten tisti za rus, ker pri tem zavaja etnik Rus (o tem že v 2.2), tako da ostaneta med tistimi, ki smo jih v gradivu upoštevali, razlage vredna samo zoonima gad (odskočiti, kot bi koga gad pičil in imeti strupen jezik kot gad zobe) ${ }^{28}$ in jazbec (spati kot jazbec, živeti kot jazbec pozimi) - nobenega PF s tema zoonimoma ni v korpusu (tudi v Gigafidi ne). Od prvih 20 zoonimov v našem gradivu ni PFZ s spužva in podgana - v že omenjeni monografiji (Keber 1996 in 1998) spužva sploh ni upoštevana, pri zoonimu podgana pa je mogoče izvedeti, da v slovenskih PFZ komponento podgana pogosto nadomešča miš. Primer: angl. as wet like drowned rat = slov. moker kot miš, franc. pauvre comme un rat $=$ slov. reven kot cerkvena miš, ruščina ima obe varianti beden kak cerkovnaja krysa/myš́).

Druga stvar, na katero je v zvezi s preverjanjem rabe PF v elektronskih korpusih treba opozoriti, je, da iskanje vedno poteka linearno. To pomeni, da je praviloma najprej (in običajno to tudi zadošča) treba kot frazno jedro vzeti kot+C-del, ${ }^{29}$ ki sta neposredno povezana $(k o t X)$, in z iskanjem »Okolica« pregledati kolokatorje. Tako velja za glagolske in pridevniške kolokatorje, ki so najpogostejši, pa tudi za prislovne, saj so vsi besednoredno (lahko in najpogosteje so) ločeni od kot+C-dela (krasti kot sraka - kradel je/bo kot sraka itd.), ne pa tudi za samostalniške, kjer je kot $X$ desni prilastek (atribut) in zato razvrščen neposredno za samostalniškim jedrom. V tem se korpusno preverjanje bistveno razlikuje od načina preverjanja stalnosti pri rojenih govorcih, kjer asociativno (mentalno) iskanje poteka sintagmatsko, torej krasti kot ... ${ }^{30}$.

3.1 Čeprav Gigafida ni uravnoteženi korpus ( $93 \%$ gradiva je iz časopisnih, revialnih in internetnih tekstov), je zaradi svoje velikosti in zato, ker se tudi frazeologija po različnih vrstah tekstov ne pojavlja uravnoteženo, primerna za ugotavljanje stopnje prisotnosti PFZ v diskurzih sodobne slovenščine, vsaj pisnih. Na podlagi iskanja, ki smo ga opisali, smo oblikovali naslednjo 5-stopenjsko lestvico in jo skušali tudi interpretirati:

$28 \quad$ Pri prvem komponento gad nadomešča kača.

29 Termin frazno jedro se uporablja v korpusnem jezikoslovju, pri nas prim. v Gantar 2007: $37 \mathrm{idr}$.

30 Zato je navajanje iskalnega izhodišča v Temnik, Kalamar 2006, npr. s. 99 ali 100, v obliki živeti kot ... ali umreti kot ... zavajajoče. Če pa bi bilo tako tudi zares iskano, bi bilo napačno - glede na povedano »Pri tem so bili upoštevani: vse glagolske oblike, časi in vsi trije primerjalni vezniki« sklepamo, da ni bilo. 
1. 0 pojavitev $(14,9 \%)$ - frazemi niso več v rabi v pisnih tekstih - časovna markiranost (problematizacijo podatka gl. 3.1.1), npr.:

debel kot polh, hud kot sršen, siten kot breja mačka, potiti se kot miš v kopi, peti kot škrjanček;

2. 1 - 9 pojavitev $(30 \%)$ - frazemi se umikajo iz splošne rabe - časovna markiranost ali neknjižnost, zlasti dialektalna označenost PFZ, npr.:

smrdeti kot medmašni kozel, spolzek kot jegulja, pijan kot muha, ležati kot krava, jesti kot pujs, žreti kot prasec;

3. 10 - 19 pojavitev $(17,5 \%)$ - raba je omejena - regionalno, starostno (generacijsko) ali zaradi premočne ekspresije (pisnost), npr.:

len kot fuks, premlatiti (koga) kot mačka, kot ovce brez pastirja, trmast kot bik, iti/lepiti se (na koga/kaj) kot muhe na drek;

4. 20 - 60 pojavitev $(22 \%)$ - frazemi so v rabi v standardni slovenščini, ${ }^{31}$ npr.: iti/ lepiti se (na koga/kaj) kot muhe na med, imeti spomin kot zlata ribica, zapreti se kot školjka, rdeč kot kuhan rak, reven kot cerkvena miš, je koga kot rusov;

5. $60 \rightarrow(14,5 \%)$ - tisti del PFZ, ki so zaradi velike pogostosti v slovenščini zadnjih 20 let zanimivi tudi sociolingvistično, npr.:

počutiti se kot riba $v$ vodi, krasti kot sraka; lagati, kot pes teče; delati (s čim/ kom) kot svinja z mehom, garati kot črna živina, (obnašati se) kot slon v trgovini s porcelanom, piti kot žolna, kot pes.

Preden v nadaljevanju relativiziramo na ta način dobljene kvantitativne podatke za razvrščanje, je že vredno omeniti, da velika večina poimenovanj za 20 najpogosteje primerjanih živali v slovenščini ( $k$ ot $X$ ) spada med komponente PFZ, ki sodijo v 5. skupino. Izjema so - poleg že razloženih spužva in podgana - le kača $\mathrm{v}$ 4. ter ris in opica $\mathrm{v} 3$. skupini. $^{32}$

\subsubsection{Relativizacija skupin}

Samo na podlagi frekvence rabe oblikovane skupine bi bilo v nadaljevanju treba najprej regulirati glede na faktor kolokabilnosti (LL). Tako se pokaže, da ima PFZ trmast kot osel sicer v Gigafidi samo 15 pojavitev, vendar pa z iskanjem kot osel v okolici 3 levo in 3 desno (od iskalnega niza) zasede trmast med vsemi kolokatorji 1. mesto. Še natančneje: ob iskalnem nizu kot polž z enakim iskanjem v okolici dobimo kot 1 . kolokator počasen (29 pojavitev) z vrednostjo LL 96, pri čemer ima naslednji kolokator LL 54:33 med pridevniškimi kolokatorji je počasen na 1. mestu z LL 114, na 2. varen z LL 9. Predvidljiva posledica upoštevanja faktorja LL bi bila višja uvrščenost PFZ

$\overline{31}$ Termin standardna slovenščina je rabljen namenoma in presega obseg knjižnega jezika predvsem v smeri pogovornosti in govorjenosti.

32 Vsaj za opica omenimo, da je tradicionalno ljudsko poimenovanje zanjo (iz nemščine prevzeto) afna, ki se pojavlja v frazemu afne guncati.

33 Čim višji je LL, tem večja je predvidljivost pojavljanja danega kolokatorja ob jedru in tem večja je stalnost PFZ. 
brez variantnih A-delov in nižja tistih z variantnimi. Še izraziteje kot v naši razvrstitvi bi se v tem primeru pokazala sociolingvistična teža korpusa s tako majhnim (kratkim) časovnim obsegom (20 let).

Kazalec večje ali manjše omejenosti v rabi je tudi primerjalni veznik. Ob nevtralnem kot kaže raba kakor po eni strani pisnost, po drugi tudi časovno daljšo prisotnost $\mathrm{v}$ jeziku; raba ko pa predvsem govorni medij. Tako npr. krasti kot sraka kaže vse troje: s 321 pojavitvami krasti kot sraka veliko frekvenco rabe sploh, s 35 pojavitvami krasti ko sraka tudi prisotnost v govorjenih tekstih (v Gigafidi so to predvsem internetni teksti) in ne nazadnje s 5 pojavitvami krasti kakor sraka dolgotrajno prisotnost v slovenščini.

3.1.2 Za manj sociolingvistično obarvano in bolj sistemsko urejeno predstavo o stanju PFZ danes bi bilo seveda nujno treba korpusne podatke soočiti z rezultati anketiranja rojenih govorcev. ${ }^{34}$ Animalistična frazeologija je v sodobnem času morda tisti del frazeologije, ki utegne postati manj aktualen. Seveda pa tega brez raziskave ni mogoče vedeti.

\subsection{Korpus in stalnost $\mathbf{v}$ frazeologiji}

3.2.1 Frazeolog, ki je predmet svojega raziskovanja opazoval v funkcioniranju (v tekstu ali diskurzu sploh), se je tudi brez podatkov elektronskega korpusa zavedal, da je stalnost sicer ena od temeljnih lastnosti frazemov, da pa frazeologija nikakor ni dinozaver. Kljub temu so podatki, ki jih ponuja korpus, lahko presenečenje, $v$ več smeri:

- s še večjo relativizacijo stalnosti - tako npr. variantni PFZ hoditi/lesti kot polž po korpusnih podatkih - vleči se (14 pojavitev), premikati se (9), lesti (8), voziti (7), plaziti se (2), hoditi (1) - dobi osnovno/slovarsko obliko Glag premikanja + kot polź;

- $\mathrm{z}$ relativizacijo variantnosti - čeprav se PFZ gledati kot tele $v$ nova vrata $\mathrm{v}$ slovarjih vedno pojavlja $\mathrm{z}$ varianto zoonima $b i k$ in se to na prvi pogled tudi rojenemu govorcu zdi samoumevno, kar je glede na stanje $\mathrm{v}$ drugih slovanskih jezikih popolna posebnost, rezultat v korpusu - gledati kot tele (66) / bik (9) $v$ nova vrata - kaže, da je variantnost vredna vsaj ponovnega preverjanja.

3.2.2 Dalje je v korpusu mogoče najti podatke o novih frazemih in njihovi razširjenosti ali o novih oblikah in rabah že znanih. Za prvo prim. zapreti se kot školjka 'postati zelo nezaupljiv' (46 pojavitev, prvič 1. 1998) in imeti spomin kot zlata ribica 'imeti slab spomin' (24 pojavitev, prvič se pojavi 1. 2006, pogosteje v letih 2010 in 2011). Samo s pomočjo korpusa je mogoče razmeroma hitro priti do pojava, da se neki frazem preko prenovitvene rabe (aktualizacija) začenja uveljavljati kot modelna tvorba. Primer tega

$\overline{34} \quad \mathrm{Z}$ anketiranjem rojenih govorcev je vsekakor mogoče preverjati poznavanje frazeologije, veliko manj pa rabo. Zlasti glede variantnosti in paradigmatike so rojeni govorci precej nezanesljiv vir (o tem že v Kržišnik 2001: 16-18). 
je frazem z izhodiščno podobo (kdo) spoznati se (na kaj) kot zajec/krava na boben 'ne spoznati se na kaj' in naslednjimi rabami spoznati se na kaj ... :

(a) ostaja zoonim in poimenovanje glasbenega inštrumenta: kot bik na orgle, kot svinja na boben, kot moji zajčki na »cukpozavno«;

(b) ostaja ali zoonim ali poimenovanje glasbenega inštrumenta: kot krava na diopter, kot prašič na matematiko, kot koza na poštevanko, kot koza na računalnik, kot cugfirer František na klavir;

(c) ne ostaja niti zoonim niti poimenovanje glasbenega inštrumenta: kot Eskim na vzrejo kamel, kot Pahor na gospodarstvo, kot moja mana [napačen zapis, prav mama, op. E. K.] na ladijske vijake.

\section{3 Česar ni v korpusu ... - vloga internetnih strani}

Tudi iskanje po internetnih brskalnikih, zlasti Google in posebej za slovenščino Najdi.si, lahko obrodi sadove. Tako smo na primer postali pozorni na zvezo zagnati/ zapoditi se kot svinja $v$ buče 'brez reda planiti kam', ki smo jo nato preverili še v Gigafidi. Razmerje med količino izkazanih rab na Najdi.si in v korpusu je povedno: medtem ko je na internetnih straneh frazem rabljen vsaj 23-krat, so v Gigafidi samo 4 zadetki. Toda dejstvo, da je eden od njih uvrščen tudi v uravnoteženi korpus Kres, je podatek, ki ga je vredno omeniti. Ker frazema ni v nobenem slovarju, so bili rojeni govorci lahko edini vir. Zveza se je izkazala za frazem z regionalno omejenostjo na gorenjsko narečje ali le njegov del. ${ }^{35} \mathrm{Ni}$ nujno, da bo $\mathrm{v}$ rabi kdaj prestopil meje regionalnosti, vendar ni nemogoče. ${ }^{36}$ Vsekakor bomo lažje odgovorili, če bomo stanje spremljali v referenčnem in uravnoteženem korpusu kakor le na razmeroma neurejenih internetnih straneh. Pri jezikoslovnem raziskovanju internet ne more nadomestiti elektronskih korpusov.

\section{Sklep}

Naše razpravljanje je sicer ves čas temeljilo na materialu primerjalnih frazemov z zoonimno komponento (PFZ), čeprav raziskava prvenstveno ni bila usmerjena posebej nanje, temveč na primerjalne frazeme (PF) v slovenščini sploh: na njihove strukturne in pomenske lastnosti ter njihovo rabo danes. Pri slednjem smo izrabili podatke, ki jih ponujajo elektronski korpusi, s čimer smo - čeprav nismo uporabili popolne korpusne analize (več o tem pristopu posebej v frazeologiji prim. Gantar 2007) - nekatere že obstoječe ugotovitve za PF (v Fink Arsovski 2002) deloma podprli, deloma ovrgli. To je bilo mogoče prav zaradi velike količine zvrstno različnega materiala v korpusnih zbirkah.

35 Za določitev bi potrebovali širšo raziskavo. Pri dosedanjem preverjanju so mi bili v pomoč študenti Oddelka za slovenistiko na Filozofski fakulteti v Ljubljani - kot že nekajkrat, se je tudi tokrat potrdilo, da rojeni govorci metajezikovno slabo presojajo paradigmatične lastnosti frazemov: trdili so na primer, da se v PFZ zagnati se kot svinja v buče zoonimna komponenta ne prilagaja $\mathrm{v}$ gramatičnem številu, čeprav je v korpusu to kljub maloštevilnosti zadetkov izkazano: "Zagnale smo se kot svinje v buče, «je Petra Majdič našla slikovito prispodobo.

36 Navsezadnje je zoonim rus v je koga kot rusov prav tako regionalno omejen (prim. v 2.2). 
Če na koncu skušamo izluščiti tisto, kar bi po našem mnenju utegnilo veljati posebej za PFZ, lahko rečemo, da je to predvsem ohranjanje pomenske sestavine 'konkretno+' v zoonimni komponenti. Posledica tega je zanesljivo ohranjanje kategorialnega pomena števnosti (in posledično kategorije števila), mogoče pa tudi ohranjanje dela konotativnega pomena pri sicer pravem intenzifikatorju kot pes. Tudi nerelevantnost kategorije spola pri zoonimni komponenti je lahko samo posledica ohranjanja denotativne pomenske sestavine 'žival' - živalska poimenovanja so glede odražanja kategorije naravnega spola s slovnično kategorijo spola tudi zunaj frazeologije omejeno distinktivna. Vprašanje, ali raba PFZ v sodobnih diskurzih upada, bi bilo glede na kulturološke danosti smiselno, ${ }^{37}$ a se ga nismo lotili.

\section{LITERATURA}

Fink-Arsovski, Željka. 2002. Poredbena frazeologija: pogled izvana i iznutra. Zagreb: FF press. Gantar, Polona. 2007. Stalne besedne zveze v slovenščini. Ljubljana: Založba ZRC, ZRC SAZU.

Grošelj, Robert. 2013. Kontrastivno o slovenskih in italijanskih primerjalnih frazemih. V: Phraseologie im interlingualen und interkulturellen Kontakt $=$ Phraseologie in Interlingual and Intercultural Contact. Fabčič, Melanija; Fiedler, Sabine; Szerszunowicz, Joanna (red.). Maribor: Mednarodna založba Oddelka za slovanske jezike in književnosti, Filozofska fakulteta (Mednarodna knjižna zbirka Zora; 95). 75-91.

Keber, Janez. 1996. Živali v prispodobah 1. Celje: Mohorjeva družba.

Keber, Janez. 1998. Živali v prispodobah 2. Celje: Mohorjeva družba.

Kržišnik, Erika. 2013. Izbiblični frazemi v novem Slovarju slovenskih frazemov. V: Die slawische Phraseologie und die Bibel = Slavjanskaja frazeologija i Biblija = Slovanská frazeológia a Biblia. Walter, Harry; Mokienko, Valerij M.; Baláková, Dana (red.). Greifswald: Ernst-Moritz-Arndt-Universität Greifswald. 114-122.

Kržišnik, Erika. 2001. Vsebina (slovenskega) frazeološkega slovarja za tujce - določitev in preizkus meril. V: Skripta 5. Zbornik za učitelje slovenščine kot drugega/tujega jezika. Kržišnik, Erika (red.). Ljubljana: Center za slovenščino kot drugi/tuji jezik pri Oddelku za slovanske jezike in književnosti Filozofske fakultete. 7-21.

Mršević-Radović, Dragana. 1987. Frazeološke glagolsko-imeničke sintagme u savremenom srpskohrvatskom jeziku. Beograd: Filološki fakultet.

Temnik, Jasmina; Kalamar, Denis. 2006. Primerjalni glagolski frazemi med slovarjem in rabo. Jezikoslovni zapiski. 12/1: 97-114.

Toporišič, Jože. 1985. Vsebinska podstava primerjalnih frazeologemov v slovenskih zbirkah pregovorov in rekov. XXI. Seminar slovenskega jezika, literature in kulture. Zbornik

37 Da bi o tem kaj povedalo razmerje med količino PFZ, ki so v skupini (1) z 0 pojavitvami v korpusu, in količino novih PFZ, si ne bi upali trditi, ker naša raziskava ni bila posebej usmerjena v odkrivanje novih PFZ, temveč bolj v preverjanje v slovarjih že prisotnih. 
predavanj. Dular, Janez (red.). Ljubljana: Oddelek za slovanske jezike in književnosti Filozofske fakultete v Ljubljani. 31-46.

Vrbinc, Marjeta. 2013. Medjezikovni vidiki angleških in slovenskih primer. V: Frazeološka simfonija: Sodobni pogledi na frazeologijo. Jakop, Nataša; Jemec Tomazin Mateja (red.). Ljubljana: Založba ZRC, ZRC SAZU. 191-198.

\section{SLOVARJI}

Anić, Vladimir. 2000³. Rječnik hrvatskoga jezika. Zagreb: Novi Liber.

Fink Arsovski, Željka et al. 2006. Hrvatsko-slavenski rječnik poredbenih frazema. Zagreb: Knjigra. [HSRPF]

Keber, Janez. 2011. Slovar slovenskih frazemov. Ljubljana: Založba ZRC, ZRC SAZU. [SSF]

Pavlica, Josip. 1962. Frazeološki slovar v petih jezikih = Rječnik slovenačkih, hrvatskosrpskih, latinskih, njemačkih, francuskih i engleskih fraza. Ljubljana: DZS.

Slovar slovenskega knjižnega jezika. Ljubljana 1970-1991 (CD-rom in spletna verzija http:// bos.zrc-sazu.si/sskj.html). [SSKJ]

Snoj, Marko. 1997. Slovenski etimološki slovar. Ljubljana: Mladinska knjiga.

Školský slovnik. 2009. Bratislava: Vydavatel'stvo Priroda, s.r.o.

\section{SPLETNI VIRI}

Fidaplus: Korpus slovenskega jezika. http://www.fidaplus.net. Dostopi: februar, marec, april 2014.

Gigafida: Korpus slovenskega jezika. http://www.gigafida.net. Dostopi: februar, marec, april 2014.

Gos: Korpus govorjene slovenščine. http://www.korpus-gos.net .

Kres: Korpus slovenskega jezika. http://www.korpus-kres.net/. Dostopi: februar, marec, april 2014.

Najdi.si. http://www.najdi.si/. Dostopi: februar, marec, april 2014. 


\section{ZUSAMMENFASSUNG}

\section{ZOONYME IN DEN SLOWENISCHEN KOMPARATIVEN PHRASEMEN}

Der Beitrag besteht aus zwei Teilen. 1. Mit der Analyse von 270 aus Wörterbüchern und einer Monographie über Tiernamen gesammelten komparativen Phrasemen, die ein Zoonym als Komponente enthalten (PFZ), stellen wir ihre struktursemantischen Eigenschaften fest. In Bezug auf die Struktur dominieren die dreiteiligen (87,6\%) vor den zweiteiligen (12,3\%), ein Teil der PFZ hat beide Strukturen. In Bezug auf die Wortarten sind die verbalen PFZ am häufigsten (53\%), gefolgt von den adjektivischen (29\%) und adverbialen (15,3\%). Die Struktur eines einteiligen Satzes weisen 2,4\% auf, es gibt kein substantivisches Phrasem.

Im Rahmen der Paradigmatik verhält sich der C-Teil (Zoonym) in der Kasus- und Numerus-Kategorie regulär (zum Teil bilden volle Intensifikatoren, z.B. kot pes (dt. wie ein Hund), eine Ausnahme), im Genus wird das Zoonym dem Substantiv im Subjekt in der Regel nicht angepasst (eine Ausnahme stellt das Zoonym im kot koza (dt. wie eine Ziege) 'blöd, dumm', das auf den Gebrauch neben Agens w ${ }^{+}$festgelegt ist). Der A-Teil ist in gut $80 \%$ nicht desemantisiert, Zoonyme im C-Teil als volle Intensifikatoren bewahren am längsten den konnotativen Teil der Bedeutung. Im 2. Teil wird die Präsenz von den PFZ in den elektronischen Korpora mit dem slowenischen Textmaterial, teilweise auch auf den Internetseiten (Najdi.si), überprüft. Es wurde eine 5-Stufen-Skala erstellt - von den Phrasemen, die nicht mehr im Gebrauch sind, über diejenigen, die in den Korpora aufgrund des sozialen oder textsortenspezifischen Gebrauchs seltener vertreten sind, bis zu den in der slowenischen Standardsprache üblichen Phrasemen, wobei die häufigsten auch soziolinguistisch erklärt werden können. Mit Hilfe von elektronischen Korpora konnten wir auch einige neue PFZ entdecken und das Festigen von Modellbildungen (spoznati se na kaj kot X na $Y$; dt. sich auskennen in etw. wie ein $X$ in $Y$ ) beobachten.

Schlüsselwörter: Phraseologie, Zoonyme, komparative Phraseme, elektronische Textkorpora 